\title{
The Activities of the Moscow Patriarchate during 1991
}

\author{
YEVGENI POLYAKOV
}

The year 1991 turned out to be the last year of the USSR. The turbulent social and political changes in public life in Russia and the former Soviet republics could not leave church life unaffected. This article, written at the end of 1991 , is a survey of events in the life of the Russian Orthodox Church (hereafter referred to as ROC) during that crucial year.

Patriarch Aleksi II gave his blessing to Boris Yel'tsin as president of the RSFSR on 10 July 1991, thereby apparently demonstrating the Moscow Patriarchate's endorsement of the democratic leadership of Russia. Then came the August coup. On the second day of this plot against the people, 20 August 1991, the patriarch noted that the president of the USSR had 'withdrawn from supreme authority in the country' (what did this word 'withdrawn' mean? Perhaps 'had been removed' or some other more precise word could have been used, for after all the patriarch later emphasised that 'the circumstances of this withdrawal remain unclear'). The patriarch went on to say that 'the consciences of millions of our fellow-citizens have been outraged, as this involves the question of the legality of the newly formed Emergency Committee,' and that 'at the present moment, we must listen to the voice of President Gorbachev and discover his attitude to the events now going on.' Thus the first, rather vaguely worded, statement from the ROC leadership came a day after the start of the coup. True, it did call on the people to 'show self-control and not permit the shedding of brotherly blood at this critical time for the Fatherland'. Surely, however, prayers for the avoidance of bloodshed would have been better coming from the lips of members of the Holy Synod of the ROC themselves, during visits to the barricades at the White House? Well, they might have been, if even one of the leading hierarchs had in fact appeared at the scene of the confrontation.

In his second statement, during the night of 21 August, the patriarch emphasised that 'the church does not and cannot give its blessing to illegality, violence and acts of bloodshed', and begged: 'the Blessed Mother of God, protectress of our city... do not leave us without the protection of your veil; save us all.' That well-known defender of human rights Fr Gleb Yakunin spent all the days and sleepless nights of the coup inside the White House, as a member of the Russian Parliament. His comment on the patriarch's second statement was: 'Well, thank God he said it, at least. But his first message was quite weak. The best thing would be for him to visit the troops, appealing to them not to fire.' The journalist Nataliya Babasyan continues the story: 'Fr Gleb sighed and hurried on to the parliamentary session. Three hours later, the Russian Parliamentary Committee for Freedom of Conscience and Religion received a telephone call - the troops had been visited by the imam of the Moscow mosque.'2 Fr Gleb was not the only Orthodox priest on the barricades. Archpriest Georgi Dokunin, head of the congregation of the Church of Christ the 
Saviour in Moscow, Fr Valeri Suslin and other Orthodox priests could be seen giving communion to the defenders of democracy, bringing them words of comfort and the support of prayer. Roman Catholic priests, ministers from Protestant congregations and Muslims are also reported to have been present among the defenders of the White House at that time.

At the Extraordinary Congress of People's Deputies of the USSR on 2 September 1991, People's Deputy A. M. Ridiger, alias His Holiness the Patriarch of Moscow and all Russia, said that 'We had no hesitation in making clear the position of the church with regard to the tragic events of August - events that shook our country as well as the rest of the world.' May we ask what, if not hesitation, can explain the evocative silence of the Moscow Patriarchate during the whole of 19 August, especially after President Yel'tsin had appealed to the patriarch that very day, saying that 'believers, the whole Russian people, the whole of Russia, are waiting for you to speak!' What, if not hesitation and uncertainty on the part of the Patriarchate, can explain the fact that their first statement, dated 20 August, generally seemed to lack any bite, compared, for example, with the Appeal from the Superintendent and the General Consistory of the United Evangelical Lutheran Church of Russia?

Dear fellow countrymen! We appeal to you, regardless of religious denomination or ethnic origin, to remain loyal to the lawful, constitutionally elected authorities of the USSR and the RSFSR. Only the peaceful restoration of M. S. Gorbachev's authority as President of the USSR and the preservation of the lawful authorities of the republics will allow us to save the country from catastrophe.

We hope that our common prayer to God may give people hope that arbitrary violence will not triumph again in our country.

We call on you to support President B. N. Yel'tsin and the Russian Parliament. In the current crisis they are the only power which can stop the plotters of the Committee, who are trying to take us back to the bloody nightmare of the communist past. May the Lord God preserve us to live a worthy life!

This statement certainly shows that on 20 August Rev. Baronas and the leaders of the United Evangelical Lutheran Church of Russia already had no doubts about their attitude to the coup.

It would certainly be unjust to say that in 1991 the leaders of the ROC made no effort to break away from the tradition of loyal relations with the communist authorities. Patriarch Aleksi, for example, spoke out in January 1991 about the military intervention in Lithuania:

In the view of the church, it is the state's duty to reconcile all groups of the population. Especially in today's world, the state authorities have no right to see any group of citizens as some kind of opposition force, against which they have to use armed force in return.... I must make it quite clear that the use of armed force in Lithuania is a great political mistake. In church language, it is a $\sin .^{3}$

Even more decisively, the senior priest of the Russian Orthodox Cathedral of the Annunciation in Kaunas, Fr Illarion (Alofeyev), expressed himself as follows:

My brethren, soldiers and officers, if you receive another order to shoot at unarmed people or to crush them under the tracks of your tanks, do not 
obey that order! Fire into the air, don't fire at all, do whatever you want, but don't shed innocent blood. Human life is precious, it is holy and nothing can atone for participation in murder.... Brothers in arms, remember you own families, your children and your motherland. No one will forgive you for murder, any blood spilt will eternally shame you, your sons and the Russian nation. Enough of blood, no more violence! All nations want peace. I beg you in the name of God, in the name of Christ, do not commit bloodshed. ${ }^{4}$

In general, however, the Moscow Patriarchate has distinguished itself by heroism after the event. Throughout the years of Gorbachev's perestroika the Moscow Patriarchate was trying neither to fall behind nor to overtake the rate at which timid democratic changes were developing, as they were administered in homeopathic doses to the citizens of the USSR by the Communist Party and the KGB. At the time of the coup, it was only in his second message that the patriarch remarked that 'conflict and bloodshed have begun.' From my own personal experience and those of others, I can confirm that the clashes in Moscow had already begun on 19 August. You didn't have to be patriarch in order to see that. From the morning of 19 August, it was clear to any student or housewife in the capital city, any passer-by or anyone participating in the numerous demonstrations, pickets and meetings protesting against the coup. (Similarly, it was only in October 1991 that we heard from the patriarch that 'Russia has suffered a severe illness in the form of communism.' $)^{5}$

During the coup, from 19 to 22 August, I myself saw the management and employees of the Moscow 'Protestant' publishing house working round the clock to reprint copies of the Russian President's decrees, proclamations by the republic's Supreme Soviet, and appeals, declarations and resolutions by official organisations and social and religious movements.

On the morning of 21 August, having heard on Radio Liberty about the patriarch's second message (issued at 1.30 a.m.), I arrived together with the journalists Aleksandr Shchipkov and Vyacheslav Chekarev at the residence of the patriarch in Chisty pereulok to try and obtain the text of this appeal. In the office, they muttered something incomprehensible in reply and advised us to visit the Danilov Monastery for this purpose. Was it really possible that the patriarch's closest colleagues, working at his own offices, did not know how important it was at that time for all Orthodox brethren and sisters in the country to hear as soon as possible what the Patriarch of All Russia had to say about what was going on in the country? People needed moral support. I think that we were not the only people who visited the patriarch's residence that day but came away empty handed.

In fairness it should be said that about an hour later, at about 2 p.m., we did indeed manage to get a copy of the patriarch's second message, at the Department of External Church Relations in the Danilov Monastery. This text had been reproduced on a photocopier. However, the patriarch's signature was not on any of the copies. I was as surprised at the absence of the patriarch's signature on such an important document as I had been by the absence of the actual document at the patriarch's residence.

What was the meaning of these and many other 'trifles'? Were they owing to selective Russian inefficiency on the part of the patriarchate's staff? Were they evidence of the subtle political cunning that had become the modus operandi of the Moscow Patriarchate? Or a mixture of the two?

Over that period of more than 50 years from the rehabilitation of the ROC in the 
USSR in 1943 until the end of 1990 , the behaviour of the church leaders had invariably to be two-faced. While preserving a resplendent outward appearance, the Moscow Patriarchate was gradually transformed into something resembling a classic Soviet institution. The course taken by the Patriarchate followed the spirit of Metropolitan Sergi's 1927 Declaration of Loyalty, and the church hierarchy was subject to the atheist authorities in all matters. For the entire half-century that its renewed official status lasted, the Moscow Patriarchate preserved a stony silence about the tragic realities of our society, under Stalin and Khrushchev, through the epoch of stagnation and even during the relatively safe six years of perestroika. The priests, largely illeducated performers of rites, were not close to the people of the church. The Patriarchate itself did not once raise its voice in defence of clergy and laity who were persecuted by the Soviet authorities. As of 31 December 1991 the ROC had still not requested that the KGB archives be opened. Meanwhile there is some evidence that secret commissions, including specialists from the Moscow Patriarchate, have been working among the documents of the reformed all-Union $\mathrm{KGB}$ and that discussions have been going on about a proposed direct transfer to the Moscow Patriarchate of the section of archives relating to religious persecution.

If this material disappears into the depositories of the ROC without being made available to the public, and if it is to lie there unused, under lock and key, we have to ask how this is preferable to its remaining where it was before. The same applies to the documents of the Council for Religious Affairs (subordinate to the USSR Council of Ministers), which was abolished on 31 December 1991.

The ROC has not yet emerged from spiritual slavery. Since the onset of glasnost' its leading hierarchs have as a rule confined themselves in their public statements to belated and mollifying presentations of problems and facts which have been covered in every newspaper and discussed by secular reporters and historians. There has been no sign as yet of efforts within the ROC to reach a real understanding between priests and their flock on the relation between faith and life in society.

The state of crisis in the ROC demands serious analysis of the basic problems: unless these are solved, the church cannot be cleansed, even after the death of the Soviet totalitarian regime at the end of 1991 . Such an analysis must involve the whole church community - all members of the church, clergy and laity, as well as representatives of the Church in Exile and the catacomb church. The forum should be an All-Russian Council (Sobor) of the Orthodox Church; to prepare for such a council, an All-Russian Orthodox Conference (Soveshchaniye) should be convened.

In an article in 1989, Fr Vyacheslav Polosin expressed the opinion that:

a key event in the history of the ROC must be a Council involving broad democratic representation. There must also be a change in religious public opinion, if possible with the cooperation of the Moscow Patriarchate, towards recognition of the canon law of 1917-18, and an essentially new church structure must be created, which would include all Orthodox Russians now in the catacombs and living abroad. ${ }^{6}$

In January 1990 the Moscow priest Sergei Popov wrote that:

The Russian Orthodox Church has become thoroughly entangled in the evil policies of the state, and has consciously associated itself with them. It must now look back to the sources of those lies which poison the consciousness of the Orthodox to this day. A new era must begin from the date of the accursed Declaration of Metropolitan Sergi, which marked the start of this 
decline. In this document satanic darkness is called light and the cruellest spiritual tyranny in history, with its bloodstained scaffold, is identified with the bright ideals of humanity.

Are our archbishops really only capable of learning from a beating? The spirit of communality must be reestablished in the church. We want to hear a true evaluation of the past and also to be informed about the church in the present, as that side of things is closed to ordinary believers. The country is on the verge of an earthquake, but the church in its present state is incapable of great deeds. Its whole structure, especially the hierarchy, is bound hand and foot by the Council for Religious Affairs, the KGB and the party ideologues. It's no use continuing to pretend that we make our own independent decisions. ${ }^{7}$

In the spring of 1990, a group of Orthodox activists put forward proposals for a Conference. ${ }^{8}$ They envisaged the following agenda:

1 A historical survey and analysis of the activity of the ROC since 1918.

2 A return, as soon as possible, to the canonical norms of the All-Russian Local Council (Pomestny Sobor) of 1917-18 and a serious theological examination of the decisions taken by subsequent Local Councils with reference to the decisions of that first Council.

3 Canonisation of all new Russian martyrs and confessors, as soon as possible.

4 Discussion by the whole church of the ecumenical activities of the Moscow Patriarchate.

5 Examination of the political actions and statements of the Moscow Patriarchate in the light of the canon laws of the Universal and the Russian Church. Evaluation of Metropolitan Sergi's 1927 Declaration and its consequences, in the light of dogma, canon law and morality.

6 Restoration of communion with the Russian Orthodox churches abroad and the catacomb church, as parts of one Russian church, to the extent permitted by canon law.

7 A survey of diocesan and parish life, in order to purify it morally and to consider present-day needs. The position of the clergy in the church. The revival of parishes and congregations as the route towards reviving the church community.

8 The church's tasks in the modern world: evangelisation, mission, pastoral teaching and charitable work. Liturgical questions. Restoration of a full church life to the non-Russian Orthodox peoples of Russia.

9 The church and the world. The church and culture. Theological definition of Christian social and political activity. The basic spiritual principles of economic activity.

10 Organisation of the task of putting archives in order and publishing documents from the archives about Russian Orthodox church life in the twentieth century.

The initiative group called on the leaders of the Moscow Patriarchate to remember the instructions of the Blessed Patriarch Tikhon, to return to the canons of the AllRussian Local Council of 1918-19, and in accordance with the will of the Orthodox people to reunite the dismembered parts of the Russian Orthodox Church.

In 1991, then, the Russian Orthodox Church found itself facing the need to 
consider a whole range of longstanding problems, for example:

1 Admitting that Metropolitan Sergi's Declaration of 1927, in which the ROC had proclaimed the 'joys' of the bolshevik state to be its own 'joys', was a false and mistaken document.

2 Reestablishing a true spirit of communality (sobornost') at all levels of church life.

3 Repenting of its services to Stalin's regime (and, in particular, condemning the 'address of welcome' on Stalin's seventieth birthday, which was signed by the patriarch, the members of the Holy Synod and the leading archbishops); and repenting of its collusion with openly antichurch policies in the period 1927 to 1985.

4 Renouncing its policy of discrimination towards the Ukrainian GreekCatholic Church and establishing fraternal relations with it.

5 Admitting its mistakes with regard to the Ukrainian Autocephalous Orthodox Church and establishing canonical and eucharistic relations with it.

6 Normalising its relations with the Roman Catholic Church.

7 Canonising all new Russian martyrs and confessors, starting with Patriarch Tikhon.

8 Condemning all forms of collaboration with the organs of state security by leading hierarchs, clergy and laity of the ROC and including in the text of the ordination oath for bishops and priests a promise not to act as an informer.

9 Opening up and publishing historical archive materials concerning the persecution of Christians during the whole period from 1917 to 1990 , now stored in the special secret archives of the KGB, the Council for Religious Affairs and other all-Soviet, republican and regional state archives.

In an open letter dated 18 May 1990 to members of the Holy Synod and the bishops and clergy of the Russian Orthodox Church members of the coordinating group preparing for the All-Russian Orthodox conference wrote as follows.

The tragedy of the Russian Orthodox Church and the tragedy of Russia itself in the twentieth century are inseparable. The blood that was spilt for the faith was also spilt for Russia. Renunciation of the church's tradition and subservience to the power of Antichrist paralysed not only the church, but also our nations, which were left without spiritual leadership and today are on the verge of ruin, having almost exhausted their reserves of spiritual resistance.... It is no longer possible to live according to the traditions established in Metropolitan Sergi's famous Declaration; we must return to the principles of the All-Russian Local Council of 1917-18 and to the precepts of the Blessed Patriarch Tikhon. Time presses....

The external problems of the ROC - living surrounded by the non-Orthodox, pursuing a dialogue with other Christian denominations and other religions, establishing relations with the state - cannot, then, be separated from its internal problems. Professor Nikita Struve has written about the ROC's supposed 'independence from the state, achieved in the two or three years of glasnost". ${ }^{9} \mathrm{Fr}$ Georgi Edel'shtein, the well-known Kostroma priest and fighter for human rights, disagrees strongly. 'The Holy Synod of the Russian Orthodox Church,' he writes,

was entirely put together 25 years ago by two institutions that did not belong to the church - the Ideological Department of the CPSU Central 
Committee and the corresponding section of the KGB of the USSR... . There is no longer an Ideological Department, even the Central Committee no longer exists and - awesome fact - the CPSU itself no longer exists; but their creations are walking round after the coup almost as if they were heroes.... The CPSU was destroyed as a cancerous tumour after the coup failed, but its growths have spread throughout the organism. ${ }^{10}$

What, then, if anything, did the fateful year 1991 do to solve these painful problems? Did the fire of democratic change do anything to purify the Patriarchate? Let us first look at some statistics which illustrate the sudden growth of the ROC and its high profile in society.

At the end of 1991, there were over 12,000 active parishes in the 93 dioceses of the ROC, as well as 117 monastic establishments, two theological academies, seven theological seminaries and 12 theological schools (for basic theological education), four schools of religious music and one postgraduate scholarship (for specialisation after higher theological education). The Moscow Patriarchate's Department of External Church Relations says that:

the number of parishes given is approximate, in view of the rapidly increasing number of new parishes. This rapid increase has meant a continuing shortage of clergymen to serve existing parishes and revive or build up new parishes. At present, the stated number of parishes have only 10,000 priests and deacons. As a result, about 20 out of every 100 churches hold services irregularly.... Problems of parish creation and training of church workers thus take priority nowadays over many other matters which the church is expected to deal with. ${ }^{11}$

In January 1991, the buildings of the Monastery of the Transfiguration were handed over to Kirov diocese. On 8 January Bishop Aleksandr of Kostroma and Galich celebrated the Divine Liturgy (for the first time since 1925) in the Holy Trinity Cathedral of the Ipat'yev Monastery in Kostroma. Moscow saw the Third International Festival of Orthodox Music (1-17 January) and the Second Festival of Orthodox Documentary Cinema (8-13 January). On 11 January the relics of Saint Serafim, the miracle-worker of Sarov, were returned to the church. Patriarch Aleksi celebrated their return with a liturgy in Leningrad. Just over six months later (from 23 July to 1 August), the relics were transferred from Moscow to Diveyevo. The Christian reporter Aleksandr Nezhny describes the occasion:

In the last week of July, Moscow walked behind the relics of Saint Serafim of Sarov. People gathered in great numbers at the Cathedral of the Epiphany and those who were lucky squeezed inside and stood there, packed tightly on all sides, sometimes hardly able to breathe. The patriarch and the archbishops and priests celebrating together with him were wearing green vestments, a colour used by the church, together with yellow and blue, to mark a man's spiritual heroism, his striving for eternal life and his victory over sin, the passions and the lower instincts. ${ }^{12}$

In Moscow and other towns, Orthodox cultural societies, centres and unions, monarchist and patriotic associations and openly nationalist organisations were formed, decomposed and reappeared, like mushrooms after rain. The ROC was becoming ideological small change in the dispute over ways of saving the fatherland. Some of its opponents saw in the Orthodox faith a panacea in the struggle against 
spiritual genocide directed against the Russian people by the wily hand of elusive Jews and freemasons, while others (for example, the ever-optimistic National Bolsheviks) have not been slow to make use of the fashionable idea of the church to decorate their shamefully tattered banners and thus win public sympathy. Yet others, with Christian and anticommunist rhetoric on their lips, have zealously tried to hypnotise mass consciousness; others still have not left the laboratories of Orthodox spirituality and have preserved a strictly apolitical attitude, favouring neither one side nor the other. This position was not the worst that could have been adopted at a time of general delusion and error. The weakened Soviet bureaucratic structures have tried to adapt themselves to the unpredictable changes in the social and spiritual sphere. It was fast becoming fashionable for officials who not so long ago were unapproachable as part of the state organisation to take up contacts with Catholic, Orthodox and Protestant clergymen. Followers of Hare Krishna, Baptists and Old Believers have been invited, almost indiscriminately, to visit maternity homes, clubs for young soldiers and institutions for juvenile delinquents. The religious boom has been gathering strength; but it would be a great mistake to confuse this with a national revival of Russian spirituality.

Amid this religious 'boom', has the ROC achieved a greater degree of inner freedom? The answer must unfortunately be 'no'.

Faithful to the Declaration of Metropolitan Sergi, the Moscow Patriarchate has preserved a strict silence on social and political developments. Taking this stance, which has become second nature over the decades, it has sometimes ended up in an extremely difficult position. While at first keeping quiet about certain problems that supposedly did not exist, the leadership of the ROC has sometimes had to retreat suddenly under the pressure of facts or of public opinion in the USSR and abroad, and start almost surrealistically to make statements contradicting its previous line. With regard to the Ukrainian Catholic Church, for example, how can we forget the immortal words uttered in October 1989 by permanent member of the Holy Synod Metropolitan Filaret of Kiev and Galich, in an interview with a correspondent of the Paris journal Express: 'The Uniates will never be legalised in our country'? They were legalised by the end of 1989 , and years of strife began between the two churches. In this context, I cannot refrain from quoting the words of the brilliant Christian journalist and defender of rights Andrei Bessmertny-Anzimirov: 'Until the Moscow Patriarchate grants freedom to the Ukrainian Catholic Church, our church, the Russian Orthodox Church itself, cannot be considered free and will remain enslaved. In Russia today, there can be no freedom for Orthodoxy without freedom for the Uniate Church.'13

Aleksandr Nezhny has described a conversation he had with KGB chief Vadim Bakatin and his deputy Anatoli Oleinikov. Nezhny asked Oleinikov whether there were clergymen who had refused to work for the KGB. The answer was extremely depressing: only 15-20 per cent had refused to do so. ${ }^{14}$

There are some 50 million Orthodox parishioners in Russia. According to Metropolitan Vladimir, at the beginning of October 1989 there were 70 dioceses in the USSR belonging to the Moscow Patriarchate, as well as 19 religious training institutions (at that time they had 3,948 students); there were $35 \mathrm{ROC}$ monasteries and convents, 13 of them recently opened. On 11 October 1989, the Moscow Patriarchate had 9,734 parishes, 8,100 clergymen and 2,433 psalm readers. Applying the 'Oleinikov figure', we may estimate that in 1989, at the time the ROC was celebrating the 400th anniversary of the Moscow Patriarchate in Russia, out of 8,100 clergy and deacons of that church in Russia, 6,480 (80 per cent) were cooperating with the KGB. 
Only 1,620 remained 'unconquered'. What would the figure be for 1991? According to official figures released by the Moscow Patriarchate in mid-autumn 1991, the ROC had a total of 10,000 clergy. Some 8,000 of them must have been cooperating to some extent with the KGB.

It should of course be made clear that hypothetical calculations regarding the murky question of the relations between the ROC and the KGB should not be confused with exact knowledge. This problem will not be solved until the archive materials are published; but in my opinion, it is hardly likely that even the democrats now in power will dare to do so, as they find it an advantage to have the Moscow Patriarchate, in its present form, as an ideological ally. Meanwhile, others make even more disturbing estimates. The well-known priest Fr Dmitri Dudko remarked in a speech at the end of November 1991 that:

to some extent, one hundred per cent of the clergy were forced to cooperate with the KGB and pass on some sort of information, otherwise they would have been deprived of the possibility of working in a parish. However, this did not affect their souls, and we still do not know whether the KGB influenced the clergy more deeply than the clergy influenced the KGB. ${ }^{15}$

On the other hand, Fr Georgi Edel'shtein has estimated the general level of cooperation at 50 per cent; and Moscow archpriest Aleksandr Shargunov, rector of the Church of St Nicholas in Pyzhi, has spoken as follows:

Indeed there were few clergymen who were able to escape the encroachments of the KGB. An innocent person might well wonder if it was worth attending a church where every second priest, according to Fr Georgi Edel'shtein, bears the mark of Judas.... I understand those priests who think it beneath their dignity to justify themselves and I am writing this merely lest our silence be interpreted by some as a sign of consent. If we are speaking of priests - let the archbishops speak for themselves - the percentage of those collaborating cannot, in my opinion, be more than one in ten. That is roughly the same as among Christ's companions at the very beginning. 16

Only the archives will reveal the truth: but they are still inaccessible. I think the reasons for this lie deeper than a lack of reading rooms. In September 1991 Vadim Bakatin, chairman of the former KGB, remarked in an interview that:

It is not so easy to seal everything or open up everything. Yel'tsin and I agreed on six months. But the moving of all our archives has been stopped and carting any of them away is forbidden. Commissions have been set up in cooperation with the Russian state archives. However, let me repeat once again - archives will be handed over to press agencies only over my dead body! I don't want to give the public the idea of settling accounts and for thousands of people that would essentially be a tragedy. ${ }^{17}$

If we are to believe Bakatin, the right time will be six months from the date of this interview - in March 1992. Will anything really have changed by then? In December 1991, with the disappearance of the USSR from the political map of the world, Bakatin was already a political corpse. How many more such corpses will we have to step over, in order to reach the truth?

The silence of the archives is paralleled by the silence of the ROC archbishops 
themselves concerning their relations with Soviet state security. All journalists, researchers and historians who have tried to touch on this sensitive subject have been greeted at best by classical silence from the Moscow Patriarchate, if not by an attempted public 'knock-out', as in the case of an official letter sent to the Moscow journal Stolitsa by the Moscow Patriarchate's Publishing Department. The attempted 'knock-out' consisted of a furious condemnation by 'employees of the Publishing Department' of some articles by Mikhail Pozdnyayev. Is there not something painfully familiar, pre-coup-like, in the demands of these 'employees' that Pozdnyayev should, for example, 'publicly apologise for his impermissible tone with regard to His Grace Metropolitan Pitirim of Volokolamsk and Yur'yev and other hierarchs of the church' and their exclamation: 'Is it your business to judge the archbishops and clergy, when you have not the slightest understanding of culture?'

The employees of the Publishing Department, so concerned at the 'tone' and level of 'culture' shown by the journalist Pozdnyayev, should perhaps have been just as concerned about Metropolitan Pitirim's failure to give them his blessing at the time of the coup. All honour to certain employees of that Department who nevertheless stayed with the people during those days of crisis, handing out copies of Moskovsky tserkovny vestnik, texts of prayers and free food at the barricades. Orthodox journalist Boris Kolymagin described the scene. ${ }^{18}$ Kolymagin had been told by 'one of the higher officials of the Department' that 'His Grace has forbidden everyone to leave their workplace. He is worried about people's safety.'

In September 1991, rumours were going round Moscow that the bank accounts of the Publishing Department, headed by Metropolitan Pitirim, had been sequestered and that a commission was at work investigating the publishing and financial activities of that department. This commission was headed by Archbishop Nikolai of Nizhny Novgorod and Arzamas. At that time, Orthodox circles did not rule out Pitirim's voluntary resignation. ${ }^{19}$ The sluggishness of the department and its head had become a melancholy tradition. For years at a time the department published nothing. There was a lot of talk, but the talking could change little. The publishing activity of the ROC became significantly more lively in the years 1985-91, but mainly because of the activities of separate dioceses, which revived the practice - banned since the 1917 Revolution - of issuing various newssheets, pamphlets and bulletins. Having realised the commercial advantages of publishing Christian literature, in 1990-1 many cooperatives and businesses put out small editions totalling millions of Bibles, Gospels and patristic literature. These editions total many times the number published over 20 years by the Publishing Department of the Moscow Patriarchate.

At the beginning of perestroika, the educational work of the ROC had reached a complete dead end. From 1985, independent underground operators and state printing houses threw themselves into the fray, as the starving market developed a taste for what had earlier been forbidden. The simplest method was to reprint nineteenthcentury editions and contemporary foreign texts. The publishing fever led to a fall in the standard of editing and to the reproduction of errors. Quite recently, a member of the Catechisation Department of the Moscow Patriarchate, who asked not to be named, told me that the academic and historical standard of the books now being published was primitive. Editorial and correcting work needed improving: there were large numbers of typographical errors and archaisms. The main need, he told me, was for faculties and training courses for 'publishers of religious literature and church journalists' in the theological seminaries of the Moscow Patriarchate and for a theological educational institution 'similar to an Orthodox theological university'.

An insoluble problem, for the time being, is that of distributing church publica- 
tions. Moskovsky tserkovny vestnik, the official Moscow Patriarchate newspaper, has been reaching its readers at unpredictable intervals. The bulletin of the ROC's Department of External Church Relations (DECR), which like Moskovsky tserkovny vestnik does not reveal its circulation figures, is published in pathetically small numbers. In 1990-1, the bulletin of the DECR was printed when it was operationally possible. The publication underwent significant change. The pages subject to Metropolitan Kirill's censorship now featured welcome items on formerly forbidden subjects: the question of relations with the Russian Church in Exile, the Ukrainian Autocephalous Church and the Greek-Catholics, reactions to the missionary activity initiated by the Vatican on the territory of the defunct USSR, and reactions to the repressions of the bolshevik regime. It should not be forgotten, however, that this bulletin is the organ of the DECR. After the ROC is purged of former KGB functionaries and the Moscow Patriarchate becomes unconditionally independent of the state (even a democratic state!) there might yet be a bulletin of the Moscow Patriarchate that would combine the positive features of the official and unofficial publications that already exist. Church people are too often misinformed, by publications which give only the official viewpoint and also, once again, by the silence of the leading bishops of the ROC. Was it right that Christians in the USSR had to learn about most events in church life under Gorbachev from Radio Liberty, the BBC and Voice of America? We must thank these radio stations - although, after my experience of working with them as a reporter, I must add the proviso that the material broadcast by the West was put out when and how the people over there thought it necessary. In recent years, then, Christians in the USSR have been forced either to swallow information about themselves as presented in the distorted mirrors of the Moscow Patriarchate, or to hear about events from the sharply anticommunist local samizdat or, most commonly, to choose the lesser evil and take up listening to western radio stations.

God willing, we will soon have an Orthodox information agency, with news services produced by experienced reporters. Various sources indicate that the Moscow Patriarchate is already taking steps in that direction. Already a wide range of movements, parties, charitable organisations and private individuals are thinking about setting up their own independent systems of information and publishing. In Moscow a Christian television and radio company called 'Blagovest"' has been founded; in December 1990 the Christian Information Agency 'KhIAG' started up; there is a new bulletin of information and analysis called Khristianskiye novosti; and early in 1991 the company 'Yulian' started producing an experimental journal Khram on church art. There have been numerous other initiatives of this kind. The strategists of the Moscow Patriarchate, indecisive for so long, risk not only irrevocably handing over the subject of the postcommunist revival in the Christian community to that community itself, but also, by so doing, deepening the already almost impassable gulf between themselves and the people of the church. This situation is made infinitely more complicated by the fact that the waste lands of ideology, information and commerce, left 'uncultivated' by the Moscow Patriarchate and Christian enthusiasts (not necessarily Orthodox), are being actively 'sown' by all kinds of specialists on the 'rebirth of the Fatherland', Orthodox fascists with a Slavocentrist philosophy who are ready to search for Jews everywhere, or bearded schoolboys from the superdemocratic weeklies who write on trendy Christian subjects....

Will a free Orthodox press succeed in coming to birth in the post-Soviet period? One can but hope. Today there is no alternative system of distributing Orthodox publications other than the 'Soyuz' press agency, nor are there any mature church 
periodicals, nor an academic journal. Some might ask, 'Isn't there the Journal of the Moscow Patriarchate?' In reply, one can only shrug one's shoulders in dismay: this journal exists, but then it doesn't really. The fact that one publication can include specifically theological, historical and informational material, current affairs journalism, a calendar of events, recommendations for liturgical practice and book reviews produces a strange sort of reaction - a feeling as if one is looking at half a dozen different journals which some eccentric has bound into one cover. Apart from everything else, the Journal of the Moscow Patriarchate is not intended for a mass audience. The recently established journal Pravoslavnaya beseda might fill the gap, as it has taken upon itself the task of catechisation and religious education. In 1992, as the Publishing Department of the Moscow Patriarchate has found out, a number of similar publications are about to appear.

New light has been shed on the work of the Publishing Department of the Moscow Patriarchate by an interesting letter from the former senior editor of the 'Church Life' section of the Journal of the Moscow Patriarchate, of which Metropolitan Pitirim of Volokolamsk and Yur'yev is in charge. Vladimir Semenko writes as follows.

Your Grace,

Recently a situation has arisen on the editorial board of the Journal of the Moscow Patriarchate which makes any creative work on the journal an absolute impossibility. The present head of the editorial staff is still 'chief secretary' K. M. Komarov - a man who is not only absolutely incompetent as a theologian (countless examples could be given) but also incapable of understanding the elementary principles of editorial or publishing work. It is precisely the harmful activity of $\mathrm{K} . \mathrm{M}$. Komarov which has blocked all attempts by the creative group formed among the editorial staff to raise the standards of the journal significantly and give it a new image corresponding to the demands of the church's situation today. Ignoring certain instructions issued by the chief editor on 1 April, K. M. Komarov continues his incompetent interference in the editorial and publishing process at various levels, insisting on using a type of material and an interpretation of problems reflected in the journal which are not just contrary to the spirit of the times but also clearly anachronistic, and which conflict with the interpretation of such problems expressed in the speeches of His Holiness Patriarch Aleksi II of Moscow and all Russia and in the resolutions of the Holy Synod. Thus, for example, every attempt is made to block the publication of material concerning the new martyrs of Russia or at least to exclude from it anything relating to the persecution suffered by the soldiers of Christ from the anti-God regime of the bolsheviks. As before, subjects banned from the JMP also include anything about the Last Judgment and the end of the world, the pains of hell, the miracles performed by God's saints etc. - that is, matters without which an adequate understanding of Orthodoxy is inconceivable. In blocking these and other subjects, K. M. Komarov is receiving support from A. S. Buyevsky, a well-known activist of the 1960s and 1970s, when the Orthodox Church was being persecuted. The absurd lengths to which supporters of an antichurch attitude are prepared to go can be seen in the removal from an article ' $N$ a poroge velikoi tainy' by G. Arkhipov of references to the famous prophecies of St Serafim of Sarov as described by S. Nilus and other widely read Church authors. A list of examples of this kind would probably take up several pages. 
The aggressive pressure exerted on the creative group among the editorial staff is accompanied by violation of the elementary ethical norms of editorial work. Thus, despite the fact that my article 'Dve svobody' had been approved by all the members of the editorial board except $\mathrm{K}$. M. Komarov, and had also been approved by the chief editor, and although the editorial staff had clearly been told this twice, at the last moment it was removed from the issue on the direct instructions of K. M. Komarov and A. S. Buyevsky. This was done behind the backs of the editorial board, after they had already decided to publish the article and although it was originally supported by the chief editor, while the author himself was not personally informed of this unexpected change of decision.

An objective and unprejudiced look at the work of the Publishing Department as a whole leads to the conclusion that of the fairly large quantity of religious literature now to be found on bookstalls in Moscow and other Russian towns, only a very small proportion is produced by the Publishing Department. At the same time, there is no news of any proposals to improve the situation.

Clearly, all the above-mentioned factors have also resulted in a significant fluctuation of manpower, in the course of which employees of the editorial department who are capable of creative work in the field of religious publishing have been leaving it.

Taking all the above into account, I ask for your Grace's blessing in accepting my resignation from my present post, on 1 August 1991.

\section{P. Semenko \\ Senior editor of the 'Church Life' section of the Journal of the Moscow Patriarchate}

19 July 1991

Metropolitan Pitirim's decision was: 'As V. Semenko in practice left his job on 19 July, let his dismissal date from the 19th.'

As we have seen, while the communist beast's spine was still unbroken, while the country was wavering between a totalitarian past and a democratic future, the Moscow Patriarchate was wavering together with the country; and the Publishing Department, led by Metropolitan Pitirim, was of course wavering too. Only after the situation finally became clear, tilting in favour of democracy, did the President of Russia, Boris Yel'tsin, receive a telegram from Patriarch Aleksi, on 22 August, hailing all those 'who courageously and uncompromisingly resisted the attempt to destroy constitutional order and legality in our unfortunate country, which is now discovering freedom....'

It is impossible that behind such men as Komarov or Buyevsky there was not the particular will of a particular individual. It is impossible that the editor in chief of the $J M P$, Metropolitan Pitirim, did not know what the chief secretary of the JMP was up to. In not allowing his employees on to the barricades at the White House during the putsch, on the pretext of being 'worried about people's safety', just whose safety was Metropolitan Pitirim of Volokolamsk and Yur'yev worried about and what consequences did he wish to avoid? Had he not used all his powers to impose silence on the JMP, as well as on other official publications of the Moscow Patriarchate's Publishing Department, concerning the tragedy of the Russian Orthodox Church? All this, in turn, gives rise to another, even more interesting question: who or what is behind Metropolitan Pitirim? 
It must be noted, as a matter of fact, that besides his unique personal passivity as a publisher of Orthodox literature, Metropolitan Pitirim was distinguished at one time for his indiscretion in accusing the newly proclaimed saint, Patriarch Tikhon, of antisovietism; in 1974 he stated that the church did not concern itself with charitable activity; not so long ago he said there was no need for religious instruction of minors. To this day Metropolititan Pitirim has made no public apology to Fr Gleb Yakunin for his judgment uttered in a 1988 interview that in the mid-1960s 'Yakunin was not tried for his faithfulness to Christianity', but 'for speculating in icons and church vestments'. In actual fact, as the archive material demonstrates, Yakunin was persecuted as a defender of human rights, under the political Article 70 of the criminal code. What can one call this? A slip of the tongue? A malicious lie? Or the metropolitan's obedience to orders 'from above'? How do orders like these square with the Holy Scriptures, which order us: 'Do not bear false witness'?

The priest and reporter on church affairs Fr Mark Smirnov has recently quoted extracts from an open letter to Metropolitan Pitirim from former political prisoner Yuri Belov, as published in the Paris newspaper Russkaya mysl' in the spring of 1980. 'I am 40 years old,' wrote Belov,

a Christian who has spent over 14 years in Soviet prisons, camps and psychiatric hospitals for his Christian convictions. After being released, I twice visited your residence at the Novodevichi Convent, in 1978 and 1979, but you refused to receive me or talk to me. After that I sent you letters on three occasions, which you also left unanswered.... Then in 1979, I was suddenly summoned by the KGB, who showed me my letters to you and threatened me with arrest. When I asked them where they had obtained my letters to you, they replied that your secretary had sent them to the KGB. I should like your activities to be known to the people whom you are shamelessly deceiving, telling them in your interviews that reports about the persecution of believers in the USSR are not founded on fact. ${ }^{20}$

Although the priests Aleksandr Borisov, Valery Suslin and Gleb Yakunin risked their lives on 19-21 August 1991 and raised the spirits of those defending democracy at the White House by joining them there, not a single member of the Holy Synod followed the example of these courageous clergymen. The uncertain statements issued by the patriarch in his own name during the coup were vague and vacillating. There are probably various reasons for this. To begin with, at the very start of the coup, the patriarch personally had no precise standpoint from which he could judge the significance of the plot. Another reason, however, is that the patriarch was probably not sure that the Holy Synod would support his viewpoint unanimously.

The coup coincided with the great feast of the Transfiguration. On the morning of 19 August, the patriarch and other higher clergy were celebrating a liturgy at the Cathedral of the Assumption in the Kremlin. The patriarch's reaction became clear when the deacon began to pray not 'for the authorities', but 'for our land and people'; it was the patriarch who had ordered the word 'authorities' to be removed and it was from his lips that the worshippers heard the words 'communist coup'. Meanwhile the three metropolitans, Kirill of Smolensk, Yuvenali and Pitirim were quite calm. Pitirim remarked in passing: 'Everything's normal.'

As we noted earlier, President Yel'tsin appealed to the patriarch to make a statement. The journalist Yakov Krotov takes up the story:

On the afternoon of 19 August, Vice-President Rutskoy phoned the 
patriarch and gave him Yel'tsin's message. The patriarch asked that his blessing be passed on to the President of Russia and promised him an appropriate reply in writing. However, the hierarchs of the church were not united. In Kiev, Metropolitan Filaret proclaimed in a sermon on the Transfiguration that normal life had begun again in the country. In St Petersburg, Metropolitan Ioann called on the inhabitants to defend the democratic authorities against the plotters. On Tuesday, the patriarch also tried to get the members of the Synod to sign a statement, but could not persuade the majority to approve. ${ }^{21}$

On 28 August, in reply to Krotov, the patriarch was assuring everyone that 'from the first hours of the coup, the bishops who were in Moscow adopted the same position as the patriarch.' The patriarch explained the fact that he alone had signed the statement by saying there had been no time to assemble 'a formal session of the Synod'. On the same day, obviously with Krotov in mind, the patriarch remarked in a letter to the chief editor of Kuranty Anatoli Pankov that 'it is a great sin to accuse people who are innocent and condemn them on the basis of distorted rumours and false interpretations'.

Krotov approves of 'his Holiness taking the responsibility on himself' ${ }^{22} \mathrm{His}$ aim, as a wise and subtle diplomat, was doubtless to defend the honour and individual reputation of the members of the Synod, the bishops and metropolitans of the ROC as a whole. After all, even if a third of the members of the Holy Synod had the foresight to keep silent during the days of the coup and another third (like Metropolitan Ioann of Leningrad and Ladoga) called on their flock to oppose the plotters, nevertheless we must assume that there were also some bishops in the Synod for whom the proclamation of a state of emergency in the USSR meant that 'normal life has begun again in our country.' It was against the latter, against men like Metropolitan Filaret of Kiev, that the patriarch finally decided not to speak out. There were probably various reasons for this. First of all, it was necessary to preserve inner unity within the highest administrative authority of the ROC during a political conflict; second, he wanted to 'keep the quarrel in the family', as they say, at a very difficult period of confrontation between the ROC and the Uniates and 'Catholic expansion' in the USSR, of growing activity by Protestant churches and interOrthodox conflicts with the Russian Church in Exile and the catacomb church; third, there was the fear that the few members of the Holy Synod accused of open loyalty to the communist plotters (sometimes jokingly known as the 'Metropolitburo') might move against the patriarch himself.

Thus in response to the criticism levelled at him by Krotov, the patriarch backed up the 13 members of the Holy Synod, both permanent and temporary, protecting them by means of his own authority. However, by the end of December 1991 it had already become clear that certain members of the ROC episcopate were cooperating with the KGB. 'We had no hesitation', said the patriarch on 2 September 1991, in a speech as a deputy at the Extraordinary Fifth Congress of Deputies of the USSR, 'in deciding on the attitude of the church towards the tragic August events'. It would be nice to believe that.

At present, a commission of deputies from the Supreme Soviet of Russia is investigating the KGB archives. According to Gleb Yakunin, a member of the commission, many unique facts about the strategy and tactics used by the state in its antichurch policies are stored in Section 4 (the 'Church Section') of the KGB's Fifth (Ideological) Department. In particular, these files contain information on some still 
active bishops of the ROC who cooperated with the state security. How far such cooperation was in accordance with canon law is for the Holy Synod to decide. Thus the Synod must decide if there is a place in the administrative structure of the Russian Orthodox Church for ROC-KGB activists of this kind - men who could reconcile their cassocks and monastic hoods with sermons proclaiming the triumph of socialism and who traded in the secrets of the confessional. (Naturally, the bitterness of knowing that the authority of the ROC had fallen so low, in the person of those bishops and clergy who worked together with the KGB, is not sweetened by the fact that the KGB also obtained cooperation from Buddhists, Muslims, Protestants, Catholics and representatives of other denominations and confessions.)

After 1927 the Moscow Patriarchate became a state Ministry for Christianity. Could it have taken a different road? Could anything have happened differently, given that the bolsheviks and their followers controlled all appointments of bishops and priests, that the secrets of the confessional were daily being violated, and that the administrative structures of the ROC, both in the Soviet Union and abroad, were full of specialists from the security services?

Fr Valeri Lapkovsky, a parish priest from Feodosiya, formerly of the Moscow Patriarchate, declared on 9 February 1991 that he was going over to the jurisdiction of the Free Russian Orthodox Church. Later he wrote as follows:

There are canon laws established in perpetuity by the Russian Orthodox Church according to which if a priest, bishop or deacon is ordained to holy orders with the assent of the state, rather than the church authorities, he is liable to be deprived of holy orders together with anyone who associates with him. These are apostolic principles. ${ }^{23}$

'If we followed these rules,' protested the journalist interviewing Fr Valeri, 'the whole Moscow Patriarchate would be liable to these penalties.' 'That is absolutely true,' Fr Valeri stated categorically:

The whole Moscow Patriarchate, from the patriarch down to the least important priest, is wholly lacking in grace. And if canon law is to be strictly observed, they could all be expelled from the Mother Church.... The leadership of the Moscow Patriarchate has no share in the blood shed by the new martyrs of Russia. The halo of martyrdom belongs to a quite different church: the Catacomb Church.

No doubt there are many people who would throw the same question at Fr Valeri Lapkovsky that the employees of the Publishing Department threw at the journalist Mikhail Pozdnyayev: 'Is it your business to pass judgment on the hierarchy and clergy?' There have been threats to Fr Valeri's life; he has been beaten up and persecuted by the Ministry of the Interior as well as being hounded by his superior, Bishop Vasili of Simferopol' and the Crimea. All this leads us to wonder what kind of state an Orthodox priest must have been reduced to by conditions in his parish and in society to have voiced judgments like these.

The aim of this survey of events in the life of the ROC in 1991 has been not so much to list the bare facts as to reflect on the church's basic problems, its relations with the state authorities and its responsibility for our spiritual past, present and future. Many people are now only approaching a church. They are at the gates of the church. The church must receive each of them and give them a warm welcome, while still remaining a church, not a home for communist or Christian .Democratic Party committees, nor a club for demonstrating national superiority, nor an official villa, 
with all the conveniences, for bishops and priests who have brought discredit on themselves.

\section{Notes and References}

Khristianskiye novosti, nos 35-9, special issues for 19-27 August 1991.

2 Nataliya Babasyan, 'Svyashchenniki na barrikadakh', ibid., p. 21.

3 Slovo Patriarkha Aleksiya $k$ sobytiyam v Litve, 15 January 1991.

4 Svobodny Kaunas, 16 January 1991.

5 Moskovskiye novosti, no. 43, 27 October 1991.

6 Fr Vyacheslav Polosin, Vestnik khristianskogo informatsionnogo tsentra (samizdat), no. 57, 26 December 1989, p. 6.

7 Fr Sergei Popov, 'O sovremennom sostoyanii Russkoi Pravoslavnoi Tserkvi', Vestnik khristianskogo informatsionnogo tsentra (samizdat), no. 10 (68), 2 January 1990, pp. 5-6.

8 Vestnik khristianskogo informatsionnogo tsentra (samizdat), 20 April 1990.

9 Vestnik russkogo khristianskogo dvizheniya, no. 160, 1990, p. 3.

10 Russkaya Pravoslavnaya Tserkov' segodyna glazami zarubezhnykh istorikov i ochevidtsev (samizdat), Kostroma-Washington, May-November 1991, pp. 1-2.

11 Informatsionny byulleten' Otdela vneshnykh tserkovnykh snoshenii Moskovskogo Patriarkhata, no. 37, 1991, p. 11.

12 Aleksandr Nezhny, 'Poslesloviye k palomnichestvu', Ogon'yek, no. 45, November 1991, p. 18.

13 A. Bessmertny-Anzimirov, 'Ob iskusstve nazyvaniya veshchei svoimi imenami', Vestnik khristianskogo informatsionnogo tsentra (samizdat), no. 7 (65), 23 January 1990, pp. 2, 4.

14 Russkaya mysl', 20 December 1991, p. 17.

15 Khristianskiye novosti, no. 53, 1 December 1991.

16 Argumenty i fakty, no. 51, December 1991, p. 6.

17 Moskovskiye novosti, no. 36, 8 September 1991, p. 6.

18 Khristianskiye novosti, nos 35-9, special issues for 19-27 August 1991, p. 19.

19 Khristianskiye novosti, no. 41, 8 September 1991, pp. 4-5.

20 Fr Mark Smirnov, ‘. . i i yesche neskol'ko shtrikov k politicheskomu portretu mitropolita Pitirima', Stolitsa, no. 43, 1991, pp. 35-7.

21 Yakov Krotov, 'Slava i pozor tserkvi', Kuranty, no. 159, 27 August 1991.

22 ibid.

23 Khristianskiye novosti, no. 30, 14 July 1991.

(Translated from the Russian by Marite Sapiets) 